\title{
PENGEMBANGAN MEDIA KOMIK UNTUK MEMBANGUN KESADARAN BUDAYA DI SMA SULTHON AULIA BOARDING SCHOOL BEKASI
}

\author{
Susi Fitri ${ }^{1}$ \\ Hilma Fitriyani ${ }^{2}$ \\ Aditya Febriansyah Ramadhan ${ }^{3}$
}

\begin{abstract}
Abstrak
Penelitian ini bertujuan untuk menghasilkan media pembelajaran berupa komik mengenai kesadaran ragam budaya yang ditujukan untuk kelas X di SMA Sulthon Aulia Boarding School Bekasi. Kesadaran budaya merupakan hal mendasar yang harus dimiliki oleh individu sebelum mereka memiliki pengetahuan dan keterampilan budaya. Menurut Sue \& Sue (2006), kesadaran merupakan salah satu kompetensi utama yang harus dimiliki dari ketiga kompetensi antar budaya. Sampel yang diambil pada penelitian sebanyak 80 peserta didik. Peneliti menggunakan teknik simple random sampling dalam pengambilan sampel. Metode penelitian yang digunakan merupakan metode pengembangan Research and Development (RnD) menggunakan model ADDIE (Analyze, Design, Development, Implementation, dan Evaluation). Hasil evaluasi formatif yang dilakukan oleh ahli media memperoleh nilai sebesar $70 \%$, penilaian ahli konten $86 \%$, penilaian peserta didik terhadap media mencapai $87.5 \%$, dan penilaian capaian kinerja peserta didik mencapai $92.5 \%$. Hasil pengembangan komik untuk membangun kesadaran budaya dikategorikan sangat baik. Komik yang dikembangkan ini berisikan mengenai cerita-cerita ragam budaya yang tiap episodenya mengandung isu budaya etnis. Komik ini akan memiliki 3 cerita dari setiap 3 isu yang berbeda, terdiri dari stereotip, mikroagresi, dan diskriminasi.
\end{abstract}

Kata Kunci: Pengembangan, Model ADDIE, Kesadaran budaya.

\begin{abstract}
This study aims to produce an instructional media in the form of comic regarding the cultural difference awareness designed for the 10th grader of Sulthon Aulia Boarding High School Bekasi. Cultural awareness is a fundamental thing that must be done by individuals before they have knowledge and skills. According to Sue \& Sue (2006), awareness is one of the virtues that must be created from all three multicultural competencies. The samples were taken from 80 students. The researcher used the simple random sampling technique to take the samples. The method used is the Research and Development (RnD) method using the ADDIE (Analyze, Design, Development, Implementation, dan Evaluation) model. Based on the assessment, the formative evaluation conducted by the media expert is $70 \%$, content expert assessment is $86 \%$, the students assessment about media is $87,5 \%$, and student assessment about learning attainment is $92.5 \%$. The result of the
\end{abstract}

\footnotetext{
${ }^{1}$ Universitas Negeri jakarta, susi.fitri@unj.ac.id

${ }^{2}$ Universitas Negeri Jakarta, hilma@unj.ac.id

${ }^{3}$ Universitas Negeri Jakarta, adityafebriansyahramadhan@gmail.com
} 
development of comic to build the cultural awareness is categorized as excellent. The developed comic is a book containing a series of diverse cultural stories. Each story presents different issues of ethnic culture. This comic portrays three stories of three different issues, namely stereotype, microagression, and discrimination. Keywords: Development, ADDIE model, cultural awareness.

\section{PENDAHULUAN}

Budaya merupakan bagian hidup manusia yang paling dekat dengan kehidupan sehari-hari. Setiap kegiatan manusia hampir tidak pernah lepas dari unsur budaya. Sebab sebagian besar dari kegiatan manusia dilakukan secara berkelompok dan tak jarang dari latar belakang budaya yang berbeda. Bila individu tidak dapat menerima perbedaan budaya dalam sosialnya, maka tandanya individu perlu meningkatkan kesadaran budaya. Kesadaran budaya merupakan hal mendasar yang harus dimiliki oleh individu sebelum mereka memiliki pengetahuan dan keterampilan budaya. Menurut Sue \& Sue (2006), kesadaran merupakan salah satu kompetensi utama yang harus dimiliki dari ketiga kompetensi antar budaya. Hal ini diperkuat oleh penjelasan Connerley dan Pedersen (2005) bahwa jika tahap kesadaran diabaikan, maka pengetahuan dan keterampilan dapat didasarkan pada asumsi yang salah.

Indonesia adalah sebuah negara yang kaya akan keanekaragaman. Indonesia terdiri dari 35 provinsi dengan budaya yang beragam pula pada masing-masing provinsi. Contohnya seperti agama, ras, etnis, kelas sosial, dan gender yang masing-masing berbeda. Keanekaragaman budaya di Indonesia berpotensi menimbulkan konflik. Pergumulan antar budaya memberikan peluang konflik manakala tidak terjadi saling memahami dan menghormati satu sama lain (Ibrahim, 2013). Rasa saling menghormati dan menghargai memang sulit hadir diantara keberagaman yang ada di tengah-tengah masyarakat Indonesia, namun kedua hal tersebut sangat penting untuk mencegah terjadinya konflik kecil yang bisa menjadi besar akibat keberagaman budaya.
Kurangnya kesadaran budaya merupakan salah satu penyebab dari adanya konflik antar budaya di Indonesia. Salah satunya, yaitu konflik yang terjadi antara warga Dayak dan Madura. Konflik antarwarga Dayak dengan warga Madura yang terjadi tanggal 18 Februari 2001 di Kota Sampit, ibu kota Kabupaten Waringin Timur, Kalimantan Tengah, berkembang menjadi kerusuhan antar etnis (Mahfud, 2011).

Kerusuhan berawal dari terbunuhnya empat keluarga Matayo (Madura) yang diduga dibunuh dan disembunyikan oleh orang Timil (Dayak) dan pada akhirnya meluas menjadi perang antar etnis. Konflik antar etnis tersebut seharusnya bisa saja dihindarkan apabila kesadaran budaya telah tertanam. Konflik tersebut salah satunya juga dapat terjadi akibat adanya isu-isu budaya serta pandangan-pandangan yang muncul antar etnis. Misalnya, adanya pandangan stereotip antar suku, lalu diskriminasi terhadap suatu suku yang masih sering muncul, serta mikroagresi. Hal ini diperkuat oleh pernyataan Yunus (2014) bahwa salah satu penyebab lain lahirnya konflik disebabkan oleh stereotip satu kelompok terhadap kelompok lain yang berbeda.

Isu-isu budaya seperti stereotip, diskriminasi, serta mikroagresi rentan terjadi dalam interaksi antar budaya, terutama di negara Indonesia yang setiap warganya berbeda-beda latar belakang budaya. Contohnya, bagaimana pandangan suatu suku merasa dirinya lebih baik dari suku lain, lalu bagaimana seseorang dari suku tertentu menganggap bahwa suku lain buruk hanya karena melihat satu orang dari suku lain itu saat melakukan kesalahan, serta adanya sindiran-sindiran kecil terhadap suatu suku yang bisa saja tidak disukai. Hal ini rentan terjadi dan merupakan pemicu dari 
konflik antar budaya. Jika saja kesadaran budaya telah tertanam pada diri setiap orang, tidak akan ada lagi stereotip, diskriminasi, serta mikroagresi yang dapat menimbulkan konflik antar budaya. Menurut Kertamuda (2011), kesadaran budaya (cultural awareness) merupakan salah satu dimensi penting dalam memahami keragaman budaya. Hal ini akan membantu dalam memberikan makna akan pemahaman terhadap perbedaan yang terjadi.

Pendidikan mengenai kesadaran tentang menghargai keberagaman budaya merupakan hal penting yang harus diberikan dimulai dari usia dini, yaitu tepatnya kepada para remaja. Istilah adolescence atau remaja berasal dari kata Latin (adolescere) (kata bendanya, adolescentia yang berarti remaja) yang berarti "tumbuh" atau "tumbuh menjadi dewasa". Istilah adolescence, mempunyai arti yang lebih luas, mencakup kematangan mental, emosional, sosial, dan fisik (Hurlock, 1980). Dalam hal ini dapat dikatakan bahwa remaja merupakan masa transisi dimana tumbuh dari masa kanakkanak menuju masa dewasa. Masa remaja juga dapat dikatakan sebagai periode peralihan. Peralihan tidak berarti terputus dengan atau berubah dari apa yang telah terjadi sebelumnya, melainkan lebih-lebih sebuah peralihan dari satu tahap perkembangan ke tahap berikutnya (Hurlock, 1980).

Remaja memiliki tugas untuk mendapatkan kematangan sosial, hal ini mencakup tugas remaja untuk mengetahui, mendapatkan, dan membangun kesadaran budaya. Santrock (2009) mengungkapkan bahwa pada transisi sosial, remaja mengalami perubahan dalam hubungan individu dengan manusia lain, yaitu dalam emosi, dalam kepribadian, dan dalam peran dari konteks sosial perkembangan sehingga kesadaran dalam menghargai keberagaman budaya tepat diberikan dan ditanamkan pada masa ini.

Pendidikan formal di sekolah merupakan salah satu ranah untuk menanamkan kesadaran budaya kepada para remaja sebagai peserta didik, dengan tujuan mengatasi atau mencegah konflik antar budaya. Jenjang SMA menjadi sasaran utama karena di masa SMA ini peserta didik sedang mengalami masa remaja tengah. Hurlock (1980), mengemukakan perubahanperubahan yang terjadi pada masa ini antara lain meningginya emosi yang pada masa awal remaja biasanya terjadi lebih cepat. Masa remaja tengah merupakan masa dimana mereka sudah memasuki tahap konvensional, yaitu berorientasi untuk menjaga sistem. Remaja mengikuti sistem moral tertentu karena memang itulah yang ada di lingkungannya tinggal, tingkah laku yang ditunjukkan untuk mempertahankan norma-norma tertentu. Tentunya hal ini membuat jenjang mereka tepat untuk ditanamkan mengenai kesadaran budaya di sekolah sehingga mereka lebih mengerti dan menerimanya dengan baik untuk kehidupannya di masyarakat. Penanaman mengenai kesadaran budaya juga diperlukan khususnya di sekolah yang memang memiliki peserta didik dari berbagai latar belakang budaya yang berbeda-beda, salah satunya SMA Boarding.

SMA Boarding biasanya dikenal dengan peserta didik yang memang dari berbagai daerah yang berbeda-beda dengan budaya yang berbeda pula. Siswa-siswa yang bersekolah di SMA Sulthon Aulia Boarding School Bekasi berdasarkan data yang ada biasanya dari daerah-daerah antara lain Padang, Betawi, Jawa, Sunda, Papua, Batam, Kalimantan, NTT, Sumatra, Palembang, Jambi, Brunei, dan Qatar. Biasanya dengan adanya perbedaan budaya tersebut, muncullah permasalahan mulai dari stereotip serta diskriminasi antar kelompok.

Berdasarkan hasil wawancara dengan seluruh guru BK SMA Sulthon Aulia Boarding School Bekasi, didapatkan hasil bahwa banyak sekali masalah yang bermunculan mengenai penghinaan dan pelecehan antar peserta didik yang berbeda latar belakang budaya di jenjang kelas 10 . Salah satu contohnya adalah dimana ada seorang siswa dari suku minoritas yang dicemooh teman-temannya hingga tidak mau sekolah dan mengurung diri di kamar asramanya. Pencemoohan ini terjadi akibat 
kebiasaannya yang berbeda dengan kebiasaan peserta didik kebanyakan.

Guru BK tersebut mengakui bahwa hal ini memang sering terjadi di jenjang kelas 10 dan biasanya mulai mereda saat mereka sudah di jenjang berikutnya. Guru BK mengaku memang selama ini mereka memprioritaskan kelas 10 untuk mendapatkan materi mengenai toleransi berbudaya. Namun, kurangnya sumber pembahasan mengenai kesadaran budaya serta media pembelajaran yang dapat digunakan di sekolah untuk mengajar mengenai kesadaran budaya merupakan salah satu penghambat guru BK membantu peserta didik dalam menumbuhkan kesadaran budaya. Penghambat tersebut membuat guru BK kesulitan dalam mengajarkan kesadaran budaya kepada peserta didik kelas 10, ditambah dengan terbatasnya waktu tatap muka guru BK dengan peserta didik di kelas.

Dengan masalah yang ada tersebut, guru BK perlu memberikan informasi melalui layanan bimbingan kelompok mengenai kesadaran budaya. Bimbingan kelompok dipilih sebagai layanan yang sesuai karena berdasarkan hasil penyebaran Cultural Awareness Self-Asessment Checklist kepada 80 peserta didik yang sama, yaitu 53\% peserta didik masih masuk kedalam kategori rendah tingkat kesadaran budayanya. Cultural Awareness Self-Asessment Checklist adalah kuesioner yang dikembangkan oleh Greater Vancouver Island Multicultural Society yang didukung oleh pemerintah Canada dan British Columbia untuk digunakan dalam mengetahui seberapa besar tingkat kesadaran budaya di negara tersebut. Bimbingan kelompok tepat diberikan untuk 53\% peserta didik yang masuk kedalam kategori rendah tingkat kesadaran budayanya. Menurut Shertzer dan Stone (1981) bimbingan kelompok merupakan bagian dari program bimbingan berbentuk suatu kelompok yang beranggotakan para peserta didik. Tujuan dasar bimbingan kelompok adalah untuk memberikan informasi mengenai perilaku dan pengambilan keputusan. Pendekatan bimbingan kelompok bersifat preventif yang berkaitan langsung dengan anggota kelompok dalam memperoleh informasi, orientasi pada masalah-masalah baru, perencanaan dan pelaksanaan kegiatan peserta didik, dan mengumpulkan data untuk pengambilan keputusan dibidang pekerjaan dan pendidikan. Materi yang dibawakan melalui layanan bimbingan kelompok tentunya harus dikemas dengan baik dan menggunakan media pembelajaran yang menarik, agar peserta didik mampu menerima secara menyeluruh materi yang diberikan. Pemberian materi mengenai kesadaran budaya ini sangat penting agar dapat membantu remaja khususnya peserta didik yang sedang mengalami masa transisi agar menyadari budayanya sendiri sehingga dapat menerima pula budaya orang lain.

Lalu berdasarkan wawancara dengan salah satu peserta didik di SMA Sulthon Aulia Boarding School Bekasi, didapatkan hasil bahwa peserta didik tidak pernah mendapat materi belajar mengenai kesadaran antar budaya. Berdasarkan data angket, didapat hanya hampir setengah peserta didik (49\%) yang merasa pernah mendapat materi mengenai toleransi perbedaan antar sesama. Sedangkan setengah $(51 \%)$ dari sisanya merasa tidak pernah mendapat materi tersebut.

Selain itu, hampir seluruh (99\%) peserta didik jenjang kelas 10 di SMA Sulthon Aulia Boarding School Bekasi merasa perlu sekali adanya pengembangan media pembelajaran yang menarik mengenai kesadaran budaya agar mereka lebih tertarik dan mudah mengerti dalam mempelajari materi tesebut. Dari hal tersebut, perlu adanya media yang dapat membantu remaja SMA dalam meningkatkan kesadaran budaya, terutama untuk peserta didik di SMA Sulthon Aulia Boarding School Bekasi. Komik merupakan media yang tepat untuk djadikan sebagai alat pembelajaran remaja untuk membangun keadaran budaya. Hal ini karena hampir seluruh $(95 \%)$ peserta didik merasa komik merupakan media yang efektif untuk dijadikan media pembelajaran terkait kesadaran budaya. Komik adalah media yang sanggup menarik perhatian semua orang dari segala usia, karena memiliki kelebihan, yaitu mudah dipahami 
(McCloud, 1993). Berdasarkan penyebaran angket kepada 80 peserta didik jenjang kelas 10 di SMA Sulthon Aulia Boarding School Bekasi, diketahui bahwa hampir seluruh (88\%) peserta didik merasa bahwa membaca komik membuat mereka lebih paham suatu hal ketimbang hanya membaca buku bacaan. Berdasarkan penelitian yang lakukan oleh Cahyawulan (2014), komik terbukti efektif dijadikan sebagai media pembelajaran di sekolah. Penelitian tersebut menunjukkan bahwa layanan informasi karir menggunakan media komik berpengaruh secara signifikan terhadap peningkatan kematangan karir peserta didik, baik pada sikap karir maupun pada kompetensi karir.

Maka dari itu, dalam penelitian ini media komik dipilih sebagai cara dalam membantu remaja dalam membangun kesadaran budaya melalui isu-isu budaya yang rentan terjadi dalam interaksi mereka dengan teman-teman yang datang dari berbagai latar belakang budaya terutama berkaitan dengan isu stereotip, mikroagresi, serta diskriminasi pada etnis.

\section{Komik}

Pengertian tentang komik dikemukakan salah satunya oleh Masdiono (1998), yaitu komik merupakan susunan gambar bercerita dan memberikan pesan-pesan pembacanya. Selanjutnya seorang komikus nasional, Koendoro (2004) mengatakan komik secara keseluruhan merupakan imaji kisah yang utuh hasil perkawinan gambar dan tulisan, dan secara parsial komik merupakan penekanan karakteristik dari segala subjek yang mampu memperkaya setting cerita, baik aspek wujud, gestur, maupun unsur imaji suara.

Komik merupakan media yang unik. Komik menggabungkan teks dan gambar dalam bentuk yang kreatif. Menurut McCloud (1993), menjelaskan bahwa komik adalah media yang sanggup menarik perhatian semua orang dari segala usia, karena memiliki kelebihan, yaitu mudah dipahami. Gambar yang sederhana di tambah kata-kata dalam bahasa sehari-hari membuat komik dapat dibaca oleh semua orang.
Menurut Tedjasaputra (2001), komik adalah cerita kartun bergambar di mana unsur gambar lebih penting daripada ceritanya. Cerita kartun bergambar bisa dijumpai dalam buku komik, majalah ataupun surat kabar. Komik banyak digemari anak-anak karena tanpa membaca tulisannya atau tanpa ada tulisan pun seseorang sudah bisa menangkap ceritanya dan tidak usah bersusah payah untuk membaca uraian yang tercantum dalam buku.

Komik bisa dijadikan sebagai media pembelajaran di sekolah, contohnya adalah penelitian Cahyawulan, Hanim, dan Herdi (2014). Penelitian tersebut menunjukkan bahwa layanan informasi karir menggunakan media komik berpengaruh secara signifikan terhadap peningkatan kematangan karir peserta didik, baik pada sikap karir maupun pada kompetensi karir.

\section{Kesadaran Budaya}

Pengertian kebudayaan menurut para ahli sangat beragam, namun dalam konteks ini kebudayaan dilihat dalam perspektif fungsinya sebagai pedoman bagi kehidupan manusia (Ibrahim, 2013). Menurut Koenjaraningrat (1979), kebudayaan adalah keseluruhan sistem gagasan, tindakan, dan hasil karya manusia dalam rangka kehidupan masyarakat yang dijadikan milik diri manusia dengan belajar. Senada dengan Koentjaraningrat, didefinisikan oleh Soemardjan dan Soenardi (1964) bahwa kebudayaan sebagai semua hasil karya, cipta, dan rasa masyarakat. Karya masyarakat menghasilkan teknologi dan kebudayaan kebendaan atau kebudayaan jasmaniah (material culture) yang diperlukan oleh manusia untuk menguasai alam sekitarnya agar kekuatan serta hasilnya dapat diabdikan untuk keperluan masyarakat.

Selain itu, Tylor (1924) mendefinisikan pengertian kebudayaan bahwa kebudayaan adalah kompleks yang mencakup pengetahuan, kepercayaan, kesenian, moral, hukum, adat istiadat, dan kemampuankemampuan serta kebiasaan-kebiasaan yang didapatkan oleh manusia sebagai anggota masyarakat. 
Kesadaran budaya adalah kemampuan seseorang untuk melihat ke luar dirinya sendiri dan menyadari akan nilai-nilai budaya, kebiasaan budaya yang masuk. Selanjutnya, seseorang dapat menilai apakah hal tersebut normal dan dapat diterima pada budayanya atau mungkin tidak lazim atau tidak dapat diterima di budaya lain. Oleh karena itu, perlu untuk memahami budaya yang berbeda dari dirinya dan menyadari kepercayaannya dan adat istiadatnya dan mampu untuk menghormatinya (Vacc., dkk., 2003).

Wunderle (2006) menyebutkan bahwa kesadaran budaya (cultural awareness) sebagai suatu kemampuan mengakui dan memahami pengaruh budaya terhadap nilainilai dan perilaku manusia. Implikasi dari kesadaran budaya terhadap pemahaman kebutuhan untuk mempertimbangkan budaya, faktor-faktor penting dalam menghadapi situasi tertentu. Pada tingkat yang dasar, kesadaran budaya merupakan informasi, memberikan makna tentang kemanusiaan untuk mengetahui tentang budaya. Prinsip dari tugas untuk mendapatkan pemahaman tentang kesadaran budaya adalah mengumpulkan informasi tentang budaya dan mentransformasikannya melalui penambahan dalam memberikan makna secara progresif sebagai suatu pemahaman terhadap budaya.

Menurut Sue \& Sue (2006), kesadaran merupakan salah satu kompetensi utama yang harus dimiliki dari ketiga kompetensi budaya. Hal ini diperkuat oleh penjelasan Connerley dan Pedersen (2005) bahwa jika tahap kesadaran diabaikan, maka pengetahuan dan keterampilan dapat didasarkan pada asumsi yang salah.

Berdasarkan hal di atas, pentingnya nilai-nilai yang menjadi faktor penting dalam kehidupan manusia akan turut mempengaruhi kesadaran budaya (terhadap nilai-nilai yang dianut) seseorang dan memaknainya. Penting bagi kita untuk memiliki kesadaran budaya (cultural awareness) agar dapat memiliki kemampuan untuk memahami budaya dan faktor-faktor penting yang dapat mengembangkan nilai-nilai budaya sehingga dapat terbentuk karakter bangsa (Kertamuda, 2011).

Berikut isu-isu budaya yang akan dimasukkan kedalam komik:

\section{1) Stereotip}

Stereotip adalah cara pandang terhadap suatu kelompok sosial dimana cara pandang tersebut digunakan pada setiap kelompok tersebut. Manusia seringnnya memperoleh informasi dari pihak kedua maupun media, sehingga manusia cenderung untuk menyesuaikan informasi tersebut agar sesuai dengan pemikirannya. Ini sudah merupakan pembentukan stereotip. Stereotip bisa berkaitan dengan hal positif atau hal negatif, stereotip bisa benar juga bisa salah, stereotip bisa berkaitan dengan individu atau sub kelompok (Mufid, 2010).

2) Mikroagresi

Mikroagresi menurut Connerley dan Pedersen (2005) berhubungan dengan kesadaran serta dimanifestasikan dengan halus mengenai bias dan diskriminasi yang banyak individu miliki dan lakukan padahal mereka tidak bermaksud melakukannya. Mikroagresi bersifat singkat, pertukaran pembicaraan sehari-hari yang berisi pesan merendahkan ke kelompok sasaran seperti etnis minoritas, wanita, dan minoritas seksual.

3) Diskriminasi

Doob dalam Liliweri (2005) menjelaskan bahwa diskriminasi merupakan perilaku yang ditujukan untuk mencegah suatu kelompok, atau membatasi kelompok lain yang berusaha memiliki atau mendapatkan sumber daya. Secara teoritis, diskriminasi dapat dilakukan melalui kebijakan untuk mengurangi, memusnahkan, menaklukkan, memindahkan, melindungi secara legal, menciptakan pluralisme budaya dan mengasimilasi kelompok lain.

Menurut Theodorson \& Theodorson (Fulthoni., dkk, 2009), diskriminasi adalah perlakuan yang tidak seimbang terhadap perorangan, atau kelompok, berdasarkan sesuatu, biasanya bersifat kategorikal, atau atribut-atribut khas, seperti berdasarkan ras, kesukubangsaan, agama, atau keanggotaan kelas-kelas sosial. 


\section{METODE PENELITIAN}

Metode penelitian yang digunakan adalah metode penelitian dan pengembangan atau dalam bahasa Inggrisnya Research and Development, yaitu metode penelitian yang digunakan untuk menghasilkan produk tertentu, dan menguji keefektifan produk tersebut (Sugiyono, 2013). Model yang digunakan adalah model ADDIE.

Model ADDIE adalah gabungan dari kegiatan menganalisis (Analysis), merancang (Design), mengembangkan (Development), mengimplementasikan (Implementation), dan mengevaluasi (Evaluation) (Rozalena dan Dewi, 2016).

Populasi dalam penelitian ini adalah seluruh peserta didik kelas $\mathrm{X}$ di SMA Sulthon Aulia Boarding School Bekasi. Jumlah peserta didik yang menjadi sampel adalah 80 peserta didik.

Teknik pengumpulan data yang digunakan dalam penelitian ini diantaranya adalah mewawancarai guru BK, mewawancarai beberapa peserta didik, serta menyebar isntrumen berupa angket dan instrumen Cultural Awareness SelfAsessment Checklist kepada peserta didik. Wawancara dilakukan untuk mengetahui permasalahan yang ada di sekolah tersebut, lalu instrumen disebarkan untuk mengetahui kebutuhan peserta didik mengenai aspek media, fasilitas, sumber daya yang diperlukan, pembuatan desain, kebutuhan bantuan diri serta informasi lain yang dibutuhkan. Instrumen Cultural Awareness Self-Asessment Checklist juga diberikan kepada peserta didik untuk mengetahui tingkat kesadaran budaya peserta didik di SMA Sulthon Aulia Boarding School Bekasi.

\section{HASIL PENELITIAN}

Pada tahap analisis, kegiatan yang dilakukan oleh peneliti adalah mengukur kesenjangan antara keadaan seharusnya dengan keadaan sebenarnya, sehingga dapat menentukan kegiatan yang dilakukan selanjutnya. Tahapan selanjutnya adalah menentukan tujuan kinerja. Kemudian menentukan karakteristik peserta didik, dan mengidentifikasi sumber-sumber yang diperlukan.

Pada tahap desain, kegiatan yang dilakukan adalah menyusun daftar-daftar tugas, menyusun tujuan kinerja. Saat menentukan tujuan kinerja, peneliti akan mengukur ketercapaian tujuan dengan membuat instrumen hasil uji coba kinerja peserta didik. Selanjutnya adalah melakukan pengujian strategi.

Pada tahap pengembangan, setelah rancangan telah ditetapkan, selanjutnya adalah membuat komik. Komik dibuat dengan bantuan seorang komikus yang akan menggambar cerita yang telah ditulis sebelumnya oleh peneliti. Jenis komik yang akan dibuat adalah komik buku yang terdiri dari 3 isu komik yaitu stereotip, mikroagresi, dan diskriminasi yang masing-masing memiliki 3 cerita dan pembelajaran yang berbeda.

Setelah komik kultural selesai dibuat, peneliti melakukan validasi desain. Validasi desain merupakan proses kegiatan untuk menilai apakah rancangan produk secara rasional lebih efektif atau tidak (Sugiyono, 2013). Validasi yang dilakukan adalah dengan menggunakan jenis evaluasi formatif dan dilakukan oleh ahli media dan ahli materi. Peserta didik pun dilibatkan sebagai bagian dari proses uji coba pilot. Dalam uji coba pilot, peneliti memberikan angket berupa angket minat terhadap media komik serta memberikan lembar kerja untuk mengukur capaian kinerja peserta didik setelah melakukan bimbingan kelompok menggunakan media komik yang dikembangkan.

Pada saat melakukan tahapan evaluasi formatif, peneliti melakukan uji kelayakan pada validator materi dan validator media setelah ensiklopedia selesai dibuat. Validator ahli materi diuji oleh dosen program studi Bimbingan dan Konseling Universitas Negeri Jakarta selaku ahli bidang multikultur. Validator ahli media diuji oleh dosen program studi Teknologi Pendidikan Universitas Negeri Jakarta.

Penilaian ahli materi dilakukan oleh ahli bidang multikultur juga sebagai dosen program studi Bimbingan dan Konseling 
dengan menggunakan instrumen berupa angket. Berdasarkan rumus perhitungan rata-rata pada evaluasi formatif, didapatkan hasil analisis penilaian yang dilakukan oleh ahli konten secara keseluruhan mencapai $86 \%$ yang termasuk ke dalam katagori sangat baik.

\begin{tabular}{clcccc}
\hline No. & Aspek & $\begin{array}{c}\boldsymbol{\Sigma} \\
\text { Butir }\end{array}$ & $\begin{array}{c}\boldsymbol{\Sigma} \\
\text { Skor }\end{array}$ & $\%$ & Kriteria \\
\hline 1. & Tema & 3 & 24 & $86 \%$ & $\begin{array}{c}\text { Sangat } \\
\text { Baik }\end{array}$ \\
2. & $\begin{array}{l}\text { Content } \\
\text { atau isi }\end{array}$ & 4 & 24 & &
\end{tabular}

Tabel 1 Hasil Validasi Ahli Materi

Penilaian ahli media dilakukan oleh dosen Teknologi Pendidikan dengan menggunakan instrumen berupa angket. Berdasarkan rumus perhitungan rata-rata pada evaluasi formatif, maka didapatkan hasil sebagai berikut:

\begin{tabular}{clcccc}
\hline No. & Aspek & $\begin{array}{c}\boldsymbol{\Sigma} \\
\text { Butir }\end{array}$ & $\begin{array}{c}\boldsymbol{\Sigma} \\
\text { Skor }\end{array}$ & $\%$ & Kriteria \\
\hline 1. & $\begin{array}{l}\text { Design } \\
\text { gambar }\end{array}$ & 3 & & & \\
2. & Cerita & 2 & & & \\
3. & Kualitas & 3 & 30 & $70 \%$ & Baik \\
& $\begin{array}{l}\text { Media } \\
\text { Cetak }\end{array}$ & & & & \\
4. & Tulisan & 1 & & & \\
5. & Bahasa & 1 & & & \\
\hline
\end{tabular}

Tabel 2 Hasil Validasi Ahli Konten

Berdasarkan hasil analisis penilaian yang dilakukan oleh ahli media secara keseluruhan mencapai $70 \%$ yang termasuk ke dalam katagori baik.

Pada tahapan melakukan pilot test, peneliti melakukan uji coba kepada kelompok kecil kepada 10 orang peserta didik. Menurut Wulandari (2016) minat belajar pada peserta didik meliputi rasa suka/senang dalam aktivitas belajar, rasa ketertarikan untuk belajar, adanya kesadaran untuk belajar, berpartisipasi dalam aktivitas belajar, dan memberikan perhatian yang besar dalam belajar. Uji coba kelompok kecil digunakan untuk menentukan efektivitas dan manfaat dari media komik. Uji coba dilakukan dalam layanan peminatan dan perencanaan individual yang dilakukan oleh peneliti.

Berdasakan hasil pilot test sebanyak 10 orang peserta didik. Maka, diperoleh hasil analisis penilaian mengenai rasa senang dalam aktivitas belajar, ketertarikan belajar, kesadaran untuk belajar, dan sikap memperhatikan yang dilakukan oleh peserta didik secara keseluruhan mencapai $87.5 \%$ yang berarti termasuk ke dalam katagori sangat baik. Lalu berdasarkan lembar kerja yang diberikan kepada peserta didik setelah aktivitas belajar untuk mengukur capaian kinerja peserta didik setelah layanan, didapatkan hasil $92.5 \%$ yang berarti termasuk dalam kategori sangat baik.

\begin{tabular}{|c|c|c|c|c|c|}
\hline 峞 & 麦 & $\underset{\text { Skor }}{\Sigma}$ & $\%$ & 气્ّ & 愛 \\
\hline \multirow{5}{*}{ 襡 } & 1 & 38 & $95 \%$ & \multirow{5}{*}{$\begin{array}{l}87 \\
5 \%\end{array}$} & \multirow{5}{*}{$\begin{array}{c}\text { Sangat } \\
\text { Baik }\end{array}$} \\
\hline & 2 & 34 & $85 \%$ & & \\
\hline & 3 & 30 & $75 \%$ & & \\
\hline & 4 & 33 & $\begin{array}{c}82.5 \\
\%\end{array}$ & & \\
\hline & 5 & 40 & $100 \%$ & & \\
\hline
\end{tabular}

Tabel 3 Hasil Uji Coba Minat Peserta Didik

\begin{tabular}{|c|c|c|c|c|c|}
\hline$\frac{n}{0}$ & Е & 以 & 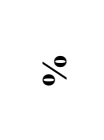 & & : \\
\hline \multirow{10}{*}{ 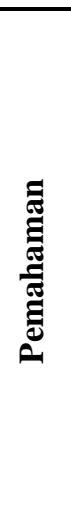 } & 1 & 10 & $100 \%$ & \multirow{11}{*}{$95 \%$} & \multirow{12}{*}{$\begin{array}{c}\text { Sangat } \\
\text { Baik }\end{array}$} \\
\hline & 2 & 8 & $80 \%$ & & \\
\hline & 3 & 10 & $100 \%$ & & \\
\hline & 4 & 9 & $90 \%$ & & \\
\hline & 5 & 10 & $100 \%$ & & \\
\hline & 6 & 9 & $90 \%$ & & \\
\hline & 7 & 10 & $100 \%$ & & \\
\hline & 8 & 10 & $100 \%$ & & \\
\hline & 9 & 9 & $90 \%$ & & \\
\hline & 10 & 10 & $100 \%$ & & \\
\hline 照 & $\stackrel{\Xi}{\Xi}$ & W & $\Delta$ & & \\
\hline$n-$ & 1 & 1000 & $100 \%$ & $90 \%$ & \\
\hline
\end{tabular}






Tabel 4 Hasil Uji Coba Capaian Kinerja Peserta Didik

Jadi, berdasarkan hasil evaluasi formatif dari ahli media, ahli konten dan peserta didik dapat dilihat melalui gambar sebagai berikut:

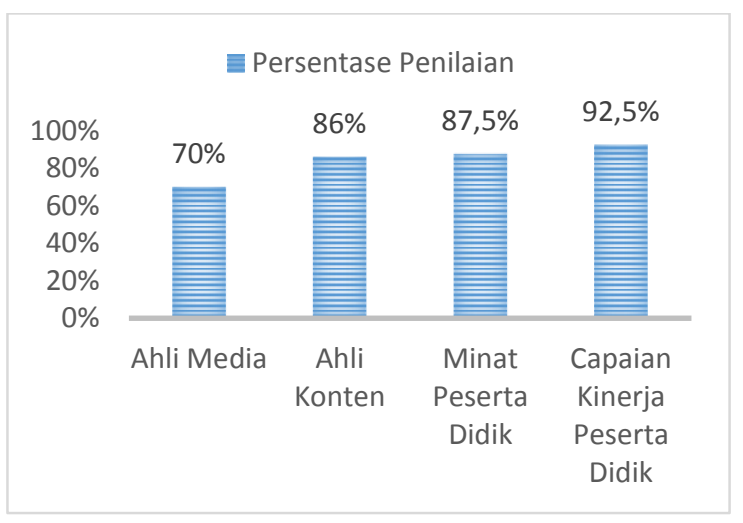

Grafik 1. Persentase Penilaian

Berdasarkan data tersebut menunjukkan bahwa hasil evaluasi formatif yang dilakukan oleh ahli media mengenai aspek yang berkaitan dengan desain gambar, kualitas media cetak, cerita, tulisan, dan bahasa mencapai $70 \%$ yang berarti baik. Hal ini dilihat dari gambar serta jalan cerita komik yang mampu memperjelas materi dan menarik, penjelasan yang mudah dimengerti, petunjuk penggunaan yang lengkap, serta tulisan dalam media yang jelas. Penilaian ahli konten yang berkaitan dengan tema dan isi mencapai $86 \%$ yang berarti sangat baik. Hal ini dilihat dari sistematika penyajian materi tersusun dengan baik, menggunakan bahasa yang baik dan benar, tema sesuai dengan karakteristik peserta didik, serta jalan cerita mengenai stereotip, mikroagresi, dan diskriminasi dalam isu etnis mudah dipahami. Penilaian peserta didik yang berkaitan dengan rasa senang dalam aktivitas belajar, ketertarikan belajar, kesadaran untuk belajar, dan sikap memperhatikan saat belajar mencapai $87.5 \%$ yang berarti sangat baik. Lalu, penilaian terhadap capaian kinerja peserta didik mencapai $92.5 \%$ yang berarti sangat baik.

Penelitian ini memiliki beberapa keterbatasan dan masih harus diperbaiki agar dapat dipergunakan secara utuh oleh peserta didik. Beberapa keterbatasan yang ada pada penelitian ini adalah:

Pertama, bimbingan kelompok saat uji pilot tidak dilakukan oleh guru BK melainkan dilakukan oleh peneliti.

Kedua, bimbingan kelompok dilakukan hanya sekali dari tiga kali pertemuan/tidak sesuai dengan Rancangan Pelaksanaan Layanan (RPL).

Ketiga, pengembangan media masih dalam penilaian yang terbatas dan tidak melalui tahap implementasi serta evaluasi dalam skala yang lebih luas, sehingga hasil penilaian media tidak dapat digeneralisir.

Keempat, pada penelitian ini, tujuan pembelajaran hanya memenuhi ranah kognitif dan belum menyentuh ranah afektif hingga psikomotorik.

\section{KESIMPULAN}

Berdasarkan hasil penelitian tentang pengembangan media komik untuk membangun kesadaran budaya, dapat disimpulkan bahwa komik merupakan media yang bisa dikembangkan untuk memberikan informasi dengan tampilan yang menarik. Pengembangan media komik untuk membangun kesadaran budaya di SMA Sulthon Aulia Boarding School Bekasi telah memenuhi komponen yang sangat baik.

Penelitian ini dilakukan dengan model Research and Development ( $\mathrm{RnD})$ yang berbasis pada pengembangan dengan menggunakan metode ADDIE. Dalam penelitian ini, peneliti hanya melakukan tahap analisis, desain dan pengembangan karena penelitian ini hanya sampai pada penyempurnaan produk pengembangan dan 
waktu yang cukup terbatas. Spesifikasi pada media ini dilengkapi dengan panduan penggunaan, isi materi, gambar animasi komik, lembar diskusi, ataupun font tulisan yang dapat menunjang penyampaian informasi melalui media komik.

Evaluasi yang dilakukan dalam penelitian ini adalah evaluasi formatif yang dilakukan oleh ahli media, ahli konten dan peserta didik.

Berdasarkan evaluasi tersebut menunjukkan bahwa tingkat validasi media mencapai $70 \%$ yang berarti baik, tingkat validasi konten mencapai $86 \%$ yang berarti sangat baik dan hasil uji coba peserta didik yang mencapai $87.5 \%$ yang berarti sangat baik. Lalu, penilaian terhadap capaian kinerja peserta didik mencapai $92.5 \%$ yang berarti sangat baik.

Pada penelitian ini ada beberapa keunggulan, kelemahan, masukan dan saran dari ahli media dan ahli konten, antara lain keunggulan pada media ini adalah format penyajian unik, sajian cocok untuk sasaran, kreatif dan bermanfaat, serta terdapat petunjuk penggunaan yang memudahkan guru BK dalam menggunakan. Adapun kelemahan pada media ini adalah desain cover yang kurang menggambarkan cerita komik dan susunan penyajian komik yang masih kurang sesuai, serta tidak memiliki daftar isi dan halaman. Masukan dan saran untuk pengembangan media ini adalah adalah perbaiki tulisan agar lebih nyaman dibaca, kurangi penjelasan yang terlalu detail mengenai suku karena khawatir justru memunculkan stereotip baru selain stereotip yang dibahas di cerita komik, perhalus sebutan-sebutan sensitif mengenai stereotip dalam materi komik agar tidak terkesan menyudutkan suatu kelompok, serta perbaiki beberapa kalimat tokoh di dalam komik agar tidak mengandung kesalahpahaman. Oleh karena itu, peneliti melakukan perbaikan media agar dapat digunakan untuk peserta didik sesuai dengan masukan dan saran para ahli. Pembahasan mengenai kesadaran ragam budaya sangat penting dalam kehidupan sehari-hari, sehingga peserta didik merasa tertarik karena media yang digunakan dan materi yang disampaikan.

Berdasarkan hasil penelitian dan kesimpulan di atas maka terdapat saransaran sebagai berikut:

Pertama, penelitian ini dapat dilanjutkan pada penelitian selanjutnya sampai pada tahap evaluasi sehingga dapat diimplementasikan kepada peserta didik dan mengetahui keefektivitasan media yang telah dikembangkan.

Kedua, penelitian selanjutnya dapat untuk mengimplementasikan media yang telah dikembangkan melalui eksperimen kepada peserta didik.

Ketiga, perihal materi mengenai kesadaran budaya sangat penting, diharapkan guru BK dapat memberikan informasi ini kepada seluruh peserta didik dengan memiliki pengetahuan yang baik mengenai kesadaran budaya sebelum memberikan materi karena media hanya sebagai pendukung saat bimbingan kelompok.

Keempat, kepada guru BK diharapkan melakukan kegiatan bimbingan kelompok secara rutin di luar jam kelas sehingga media seperti komik ini dapat bermanfaat.

Kelima, penelitian ini bisa dilanjutkan dan dikembangkan pada penelitian selanjutnya dengan memperluas tujuan pembelajaran sampai pada ranah psikomotor.

\section{DAFTAR PUSTAKA}

Cahyawulan, W., Hanim, W., \& Herdi, H. (2014). Pengaruh penggunaan media komik dalam layanan informasi karir untuk meningkatkan kematangan karir: Studi kuasi eksperimen terhadap peserta didik kelas VIII di SMP Labschool Jakarta. INSIGHT: Jurnal Bimbingan dan Konseling, 3(2), 143-149.

Connerley, M. L., \& Pedersen, P. B. (2005). Leadership In a Diverse and Multicultural Environment: Developing Awareness, Knowledge, and Skills. London: Sage Publications.

Hurlock, E. B. (1980). Psikologi Perkembangan: Suatu Pendekatan Sepanjang Rentan Kehidupan. Jakarta: Erlangga. 
Ibrahim, R. (2013). Pendidikan Multikultural: Pengertian, Prinsip, dan Relevansinya dengan Tujuan Pendidikan Islam. ADDIN, 7(1), 12-154.

Kertamuda, F. (2011). Konselor dan Kesadaran Budaya (Cultural Awareness). Jurnal Universitas Paramadina, 6(1), 11-27.

Koendoro, D. (2004). Yuk Bikin Komik Sambil Tertawa. Bandung: Mizan.

Liliweri, A. (2005). PRASANGKA \&KONFLIK : Komunikasi Lintas Budaya Masyarakat Multikultur. Yogyakarta: LKiS Yogyakarta.

Mahfud, C. (2011). Pendidikan Multikultural. Yogyakarta: Pustaka Pelajar.

Masdiono, T. (1998). Empat Belas Jurus Membuat Komik. Jakarta: Creative Media Jakarta.

McCloud, S. (1993). Understanding Comics. New York: HarperCollins.

Mufid, M. (2010). Etika dan Filsafat Komunikasi. Jakarta: Kencana Prenada Media Group.

Rozalena, A., \& Dewi, S.K. (2016). Panduan Praktis Menyusun dan Pelatihan Karyawan Pengembangan Karier. Jakarta: Raih Asa Sukses.

Santrock, J.W. (2009). Life-Span Development. Jakarta: Erlangga.

Sue, D.W. (2006). Multicultural Sosial Work Practice. New Jersey: John Wiley \& Sons, Inc.

Sugiyono. (2013). Metode Penelitian Pendidikan Kuantitatif, Kualitatif, dan $R \& D$. Bandung: Alfabeta.

Tedjasaputra, M. S. (2001). Bermain, Mainan, dan Permainan. Jakarta: Grasindo.

Wulandari, D. A. (2016). Pengembangan Media Pembelajaran Menggunakan Sparkol Video Scribe dalam Meningkatkan Minat Belajar Siswa Pada Mata Pelajaran IPA Materi Cahaya Kelas VIII di SMP Negeri 01 Kerjo. (Skripsi). Universitas Negeri Semarang, Semarang.

Yunus, F. M. (2014). Konflik Agama di Indonesia dan Solusi Pemecahannya. Substantia, 16(2), 217-228. 